\title{
CORRELATION OF DEMERIT POINT SCORE (DPS) AND CHEMICAL PARAMETERS ON QUALITY OF FRESH ESTUARY GROUPER (Epinephelus tauvina) DURING STORAGE IN ICE
}

\section{Korelasi Demerit Point Score (DPS) dan Parameter Kimia pada Kualitas Ikan Kerapu Lumpur (Epinephelus Tauvina) Selama Pengesan}

\author{
Farida Ariyani ${ }^{1 *}$, Yusma Yenni, and Rudi Riyanto ${ }^{1}$ \\ ${ }^{1}$ Research and Development Center for Marine and Fisheries Product Processing and Biotechnology, \\ JI. K.S. Tubun Petamburan VI, Central Jakarta 10260, Indonesia, *Correspondence Author: idapoernomo@yahoo.co.id
}

Article history:

Received: 16 Mei 2014; Revised: 9 Juni 2014; Accepted: 3 Juli 2014

\begin{abstract}
Quality changes of fresh estuary grouper (Epinephelus tauvina) fish kept in ice was evaluated for sensory and chemical parameters during 21 days of storage. Fish was killed by immersing in ice water (hypothermia). Fresh fish was placed in insulated boxes, and covered with ice flake. The ratio of ice and fish was $2: 1(\mathrm{w} / \mathrm{w})$ and the boxes were kept at ambient temperature. Evaluation was conducted every 3 days for sensory characteristics by Demerit Point Score /DPS for appearance, eyes, gills, belly, vent, and belly cavity. Moreover, Total Volatile Base/TVB, Trimethyl Amine/TMA , and the $\mathrm{K}$ value were measured until fish was rejected by panelists. The results showed that estuary grouper fish stored in ice was rejected by panelists on 21 days of storage with TVB value of $29.43 \mathrm{mgN} \%$, TMA value of $22.10 \mathrm{mgN} \%$ and $\mathrm{K}$ value of $40.54 \%$ (max level of $60 \%$ ). Related to correlation between sensory and chemical parameters, it showed that Demerit Point Score correlated well with TVB, TMA and $\mathrm{K}$ value.
\end{abstract}

Keywords: DPS, estuary grouper (Epinephelus tauvina), ice storage, chemical characteristics

\begin{abstract}
ABSTRAK
Perubahan kualitas kesegaran ikan kerapu ((Epinephelus tauvina) selama 21 hari penyimpanan dalam es telah dikaji secara sensori maupun kimiawi. Ikan dimatikan dengan merendamnya di dalam air es (hypothermia). Ikan segar dimasukkan ke dalam cool box dengan dilapisi es curai dengan perbandingan antara ikan dan es $1: 2 \mathrm{~b} / \mathrm{b}$, selanjutnya cool box disimpan pada suhu ruang. Evaluasi dilakukan setiap 3 hari terhadap parameter sensori dengan metoda Demerit Point Score/DPS (kenampakan, mata, insang, perut, anus, rongga perut), Total Volatile Base/TVB, Trimethyl Amine/TMA, dan K value sampai ikan dinyatakan ditolak panelis. Hasil penelitian menunjukkan bahwa ikan kerapu lumpur yang disimpan dalam es telah ditolak panelis pada 21 hari penyimpanan dengan nilai TVB $29,43 \mathrm{mgN} \%$, TMA $22,10 \mathrm{mgN} \%$ and $\mathrm{K}$ value $40.54 \%$. Hasil penelitian juga menunjukkan bahwa DPS berkorelasi positif dengan TVB, TMA dan $\mathrm{K}$ value. Kata Kunci: DPS, kerapu lumpur (Epinephelus tauvina), pengesan, karakteristik kimia
\end{abstract}

\section{Introduction}

Grouper is one of coral fish having high valuable market fishes in Southeast Asia. Indonesia is now one of major farmed-grouper producing countries in Asia. In addition, Indonesia is the largest producer and exporter of grouper seed, and whole live fish for consumption (Sugama, 2013). There are 7 general of grouper available in Indonesia, and amongs them, fish having potency for export are including polkadot grouper/panther grouper (Cromileptesaltivelis), carpet cod (Epinephelus fuscoguttatus) and estuary grouper (Epinephelus suillus).
Fish quality is clearly influenced by the freshness. Loss of freshness followed by spoilage is a complex combination of microbiological, chemical and physical processes. During handling and storage, quality deterioration of fresh fish rapidly occurs and limits the shelf life of the product, since fish is one of the most highly perishable food products. Preservation in ice is one of the most efficient ways of retarding spoilage. The rate of deterioration during ice storage of fish varies with species and depends on condition of catching/harvesting as well as handling, where fish handled and kept at higher temperature will be spoiled faster than that handled and kept at lower temperature 
(David and Tom, 2006; Ghaly et al., 2010; Massaquoi et al., 2011)

To estimate the qualtiy of both fresh and processed fish, it is necessary to analyse parameters reflecting sensory, chemicals and microbiological characteristics. The organoleptic evaluation of fish quality is the most easy and rapid technique and the most satisfactory method of assessing the freshness quality of fish, since the methods can be very fast, reliable, non-destructive on raw fish and no expensive instruments are needed (Martinsdo'ttir, 2002). Several sensory methods have been developed, including Demerit Point Score developed by the Tasmanian Food Research Unit (Branch \& Vail 1985). Demerit Point Score is a descriptive, fast and simple method to determine freshness quality and useful because it evaluates those sensory parameters and attributes that change most significantly in each species during degradation processes (Bremner et al., 1987). Since sensory method is a subjective method, therefore to obtain representative results, it should be performed by trained panelists. Comparative studies to established correlation between sensory and chemical parameters such as TVB, TMA and Kvalue are also necessary.

Many studies on sensorial and chemical properties of fresh fish during storage have been published (Jeyasekaran et al., 2005; Siah \& Afif, 2007; Ozogul et al., 2008; Okoro et al., 2010; Ariyani et al., 2011, Sulieman et al., 2012; Ariyani \& Triwibowo, 2013), however, it is necessary to evaluate the deterioration of fresh estuary grouper during storage in ice, since the changes of fish freshness during ice stoage varies with species.

\section{Material and Methods}

Raw material used in this experiment was obtained from live estuary grouper (average body weight : 300 $-450 \mathrm{~g}$ ) harvested from net-cage grouper mariculture in Lampung, washed with freshwater and killed by immersing in ice cold water (hypothermia) for approximately 20-30 min. Ungutted whole fresh grouper of $12 \mathrm{~kg}$ was placed a in insulated boxes with capacity of $50-60 \mathrm{~kg}$, covered with ice flakes in a ratio of ice and fish of 2:1 (w/w) and the boxes were kept at ambient temperature. The treatment was conducted in 7 replicates.

Samples were withdrawn every 3 days and evaluation was conducted for sensory characteristics by Demerit Point Scor/DPS developed by the Tasmanian Research Food Unit (Branch \& Vail, 1985), Total Volatile Base/TVB, Trimethyl Amine/TMA, and $\mathrm{K}$ value were according to Miwa \& Ji method (1992) until fish was rejected by panelists. The changes of sensory characteristics was evaluated by 6-7 trained panels for certain attributes (appearance, eyes, gills, belly, vent, belly cavity) with score of 0 for the best quality and 3 for the worst quality. The scores for separate attributes were summed to give an overall score. The character of fresh cooked (odour, flavour and texture) grouper was analyzed using the Torry Scheme (Huss, 1995) in which scores are given from 10 (very fresh in taste and odour) to 3 (spoiled).

\section{Results and Discussion}

Results of the observations and tests, indicated that the quality of fresh estuary grouper decreased significantly with the increase of storage time reflected by the changes of quality parameters.

\subsection{The Changes of Sensory Characteristics}

Evaluation of sensory characteristics of raw fish was conducted on general appearance, eyes, gills, belly, vent, and belly cavity with total demerit point score from 0 (as minimum score) to 30 (as a maximum score), where 0 represented best quality and a higher score indicated poorer quality. Assessment of cooked fish was conducted on odour, taste and texture with a minimum average score of 0 and a maximum average score of 10 . The results of sensory evaluation are presented in Figure $1-3$.

In the first three days of storage, there was a considerable increase in the scores obtained for general appearance, eyes and gills color, while the scores for belly, belly cavity and vent were relatively constant in this period. Scores for general appearance, eyes and gills did only slightly increase in the next six days. For all sensory characteristics, except for general appearance, there was a considerable increases in scores from day 9 of storage (Figure 1)

The general appearance attribute actually consists of several attributes i.e., appearance, skin, scales, mucus and firmness. The scores of general appearance was increased considerably in day 3 and decreased on day 6 , relatively constant up to 12 days storage and subsequently increased gradually until the end of storage. Considerable increase in day 3 was due to considerable increase of score for mucus attribute, which reaching demerit point score of 1.1 with mucus characteristics thick but not sticky. In subsequent storage (on day 6), however, scores of mucus decreased significantly and almost constant in the remaining of storage, which might be due to dissolution of mucus in ice water resulted from ice melting. This resulted in decrease in general appearance score since other scores (appearance, skin, and scales) were relatively constant. 

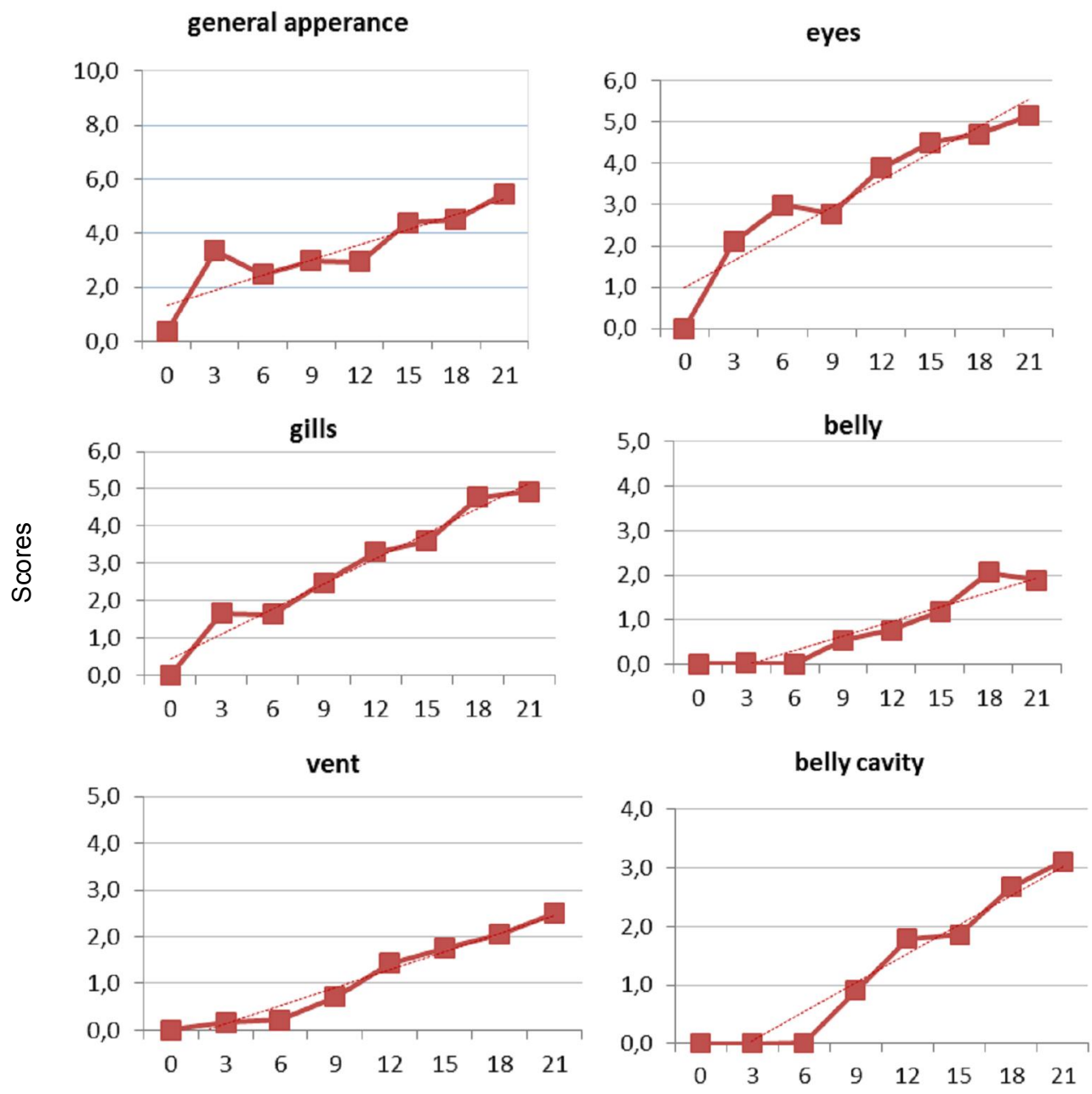

Storage Time (days)

Figure 1. The changes of sensory characteristics (general appearance, eyes, gills, belly, vent, and belly cavity) of fresh grouper fish during icing.

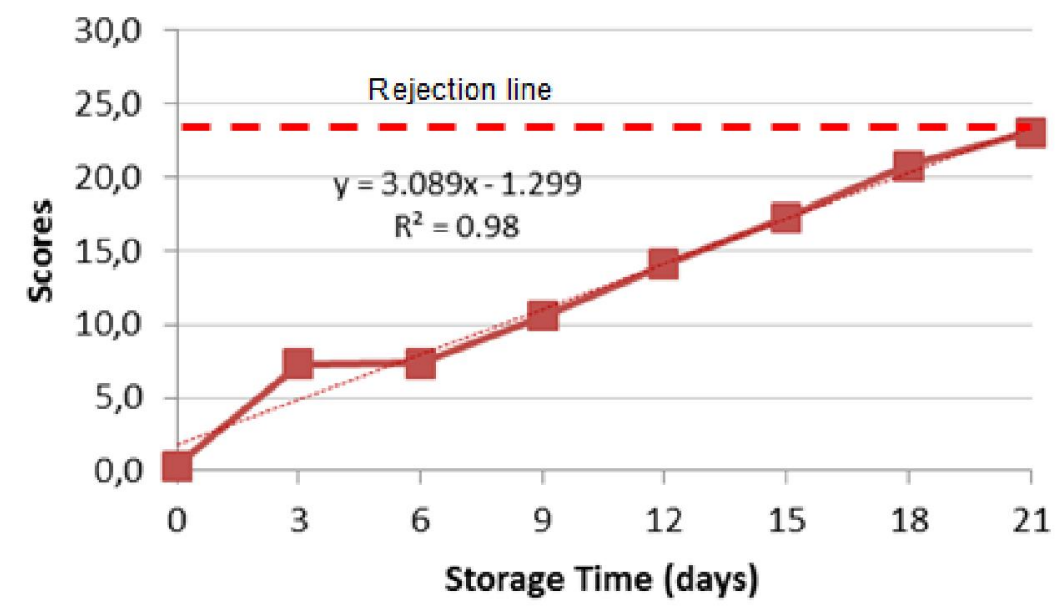

Figure 2. The changes of Torry Scores of cooked grouper fish during icing. 


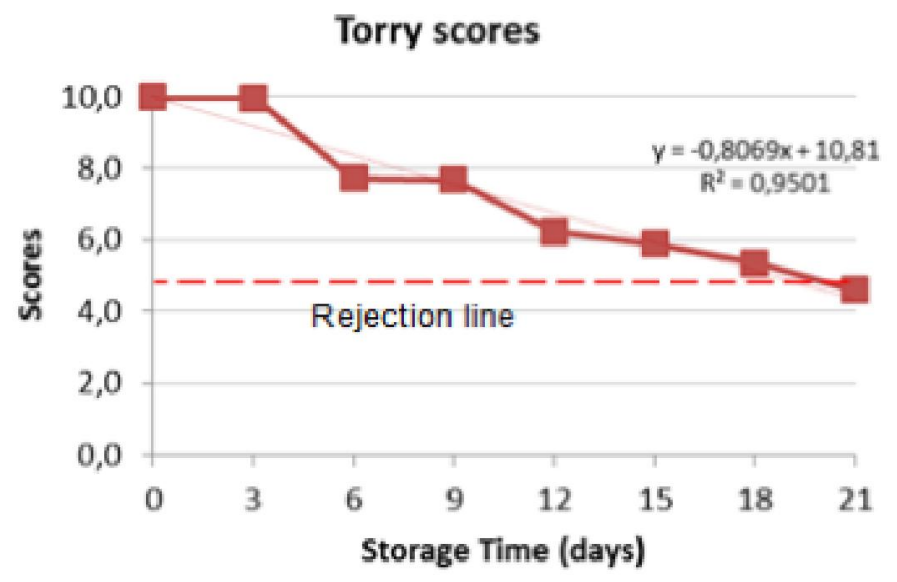

Figure 3. The changes of Torry Scores of cooked grouper fish during icing.

The thick surface mucus found in the early storage is not resulted from spoilage process, but due to stress condition during handling and transportation. The live fish in this experiment was harvested from Lampung waters and road transported to Jakarta and was killed by immersing in ice water (hypothermia) in Jakarta Laboratory. When the fish in stress condition, mucus secretion is greatly stimulated increasing the thickness of the mucus blanket (Esteban, 2012). Hur et al. (2013) stated that high frequencies of mucussecreting goblet cells were found in the digestive tract, mainly in the anterior intestine portion and pyloric ceca. One of the compound responsible in producing mucus in orange spotted grouper (Epinepheluscoioides) is a defensin like proteins, contributing to the innate host defense in multiple ways (Masso-Silva \& Diamond, 2014).

On the day 9 of storage, the belly was still firm, no discoloration, with belly cavity stain was grayish and vent was in normal condition. This could be associated with grouper skin characteristic which is firm, resulted in longer time to spoilage bacteria entering the flesh. After 18 days of storage, the belly was soft, and discoloration was detectable, belly cavity was grayish turn to yellow with dark-red bloods, vent was still normal but fishy, the gills were faded, with moderate mucus and slightly stale in odour, the eyes were slightly cloudy, slightly bloody and sunken. When storage time reaching up 21 days, the belly was soft, with detectable discoloration while the belly cavity was yellowish turn to brown, with brown blood, vent was slightly exudes and fishy smell, the gills were very faded with moderate mucus and stale in smell.

When the scores of separate attribute were summed, overall scores was obtained as Total DPS. The minimum score $(0)$ reflects the most fresh condition while the maximum score $(30)$ reflects the most deteriorated condition. During storage, DPS increased coincided with the decreased of the freshness of grouper fish and until 18 day of storage grouper fish was still acceptable having DPS of 20.8, while on the 21 day of storage the grouper fish was considered unacceptable judged by trained panel with approximate score of 23.0 (Figure 2). Ozogul et al. (2008) reported that the acceptable shelf life of white grouper was found to be 16 days for iced corresponding with a demerit score of 20.8 , while Jeyasekaran et al., 2005 observed quality changes in ice-stored of reef cod (Epinephelusmerra) found that on the $19^{\text {th }}$ day of storage, the fish was sensorily unacceptable.

The cooked grouper fish assessed by Torry-scale indicated that during storage the scores decreased linearly as the storage time increased $(R=0.95)$ as shown in Figure 3. At the time of rejection (on the 21 days of storage), the score was approximately 4.6. During the first three days of storage, the highest Torry scores (10) remained constant, and the following storage the scores decreased subsequently reaching up 5.4 on day 18 and drop to 4.6 at 21 days of storage. At the beginning of the storage time the smell of cooked estuary grouper was fresh with species characteristics, the taste was sweet and juicy, and the texture was firm, elastic and springy. On the other hand, on 21 days of storage, the smell was stale, the taste was musty, slightly sour and off flavor while the texture was slightly soft and sandy like. This result supports the finding of Ozogul et al. (2008) explaining that white grouper fish was rejected at 19 days in ice in term of cooked fish having score of 5.30. Related to cooked fish, wild and culture sea bream (Sparusaurata) kept in ice was also unacceptable on days 19-23 having score of 4.0 (Alasalvar et al., 2002). 
According to Martinsdottir et al. (2001), the average score of Torry-scale of 5.5 has been used as the limit for consumption.

\subsection{The Changes of Chemical Characteristics}

\subsubsection{Total Volatile Base (TVB)}

One of parameters widely used to evaluate fish quality is TVB, representing the sum of ammonia, DMA, TMA and others basic nitrogenous compounds volatile. In the early stage of storage, TVB values slowly increased and increased more rapidly in the remaining time of storage. According to Etienne et al. (2005) TVB-N remains constant for the first days of storage or increases slowly but rises fast later in the spoilage since they only rise as a result of the bacterial activity during later stages of deterioration

At the beginning of storage in this study, TVB value was $2.58 \mathrm{mgN} \%$ and on the $18^{\text {th }}$ day of storage TVB value reached $24.63 \mathrm{mg} \% \mathrm{~N}$ as an acceptable value and increased significantly at the time of rejection reaching up $29.3 \mathrm{mg} \% \mathrm{~N}$ (Figure 4 ). The maximum TVB value that unfit for human consumption is varied depending on the species, and European Committee classified into 3 groups, i.e., Sebastes spp. (25 $\mathrm{mg} \% \mathrm{~N})$, Pleuronectidae family flat fish $(30 \mathrm{mg} \% \mathrm{~N})$, Merluccidae and Gadidaefamilies, cod and related species $(35 \mathrm{mg} \% \mathrm{~N})$ (Howgate, 2010). Ozogul et al. (2008) who stored white grouper fish (Epinephelusaeneus) in ice found that when the grouper was rejected in term of sensory assessment, TVB value reached up to $28.8 \mathrm{mgN} \%$. On the first day of storage TVB value of white grouper was $15.4 \mathrm{mgN} \%$, while TVB value on day 0 (at the beginning of storage) in this experiment was $2.58 \mathrm{mgN} \%$. This difference was clearly due to different species and also different in catching and handling of fish. In this experiment, cultured fish was live transported to the laboratory, and on arrival at the laboratory, fish was killed and immediately sampled to chemical, microbiological and sensory analysis, hence the condition was very fresh. On the other hand, white grouper was caught from the sea, kept in crushed ice on board, delivered to the laboratory in dead condition and sampled on the 1 day of storage. Sulieman et al. (2012) also stated that at the first day of storage Total Volatile Nitrogen (TVN) of frozen greasy grouper was estimated at $8.4 \mathrm{mg} / 100 \mathrm{~g}$, and after 25 days of storage the TVN increased reaching its marginal acceptable limit (29.4 $\mathrm{mg} / 100 \mathrm{~g}$ ).

\subsubsection{Trimethylamine (TMA)}

Trimethylamine (TMA) arises from the bacterial reduction of TMAO (Malle et al., 1986) and development of TMA in seafood depends primarily on the content of the substrate trimethylamine-oxide (TMAO) in the fish as raw material (Anon.,2009).

Similar pattern to the changes of TVB value during storage, TMA values slowly increased in the beginning of storage and increased more rapidly in the remaining time of storage (Figure 4). On the $18^{\text {th }}$ day of storage TMA value reached $18.75 \mathrm{mg} \% \mathrm{~N}$ and the grouper fish was still acceptable by panelists, while on the $21^{\text {th }}$ day of storage grouper fish was rejected by panelist having TMA of $19.7 \mathrm{mgN} \%$. Ozogul et al. (2008) observed the deterioration of white grouper during icing and pointed that on the $22^{\text {th }}$ day of storage, white grouper was rejected by panelis having TMA value of $17.38 \mathrm{mgN} \%$. Different from the results of this study, as well as Ozogul finding (Ozoul et al., 2008), the TMA value of yellow grouper (Epinephelusawoara) was still low i.e., approximately $1.7 \mathrm{mgN} \%$ although the storage time was already 16 days (Wei et al., 2010). This is due to the different handling and processing used for both experiments. The yellow grouper used in Wei's study was in fillet form and vacuum packed in polyethylene bag, while estuary grouper used in this study was in a whole form, ungutted and kept in

\section{TVB}

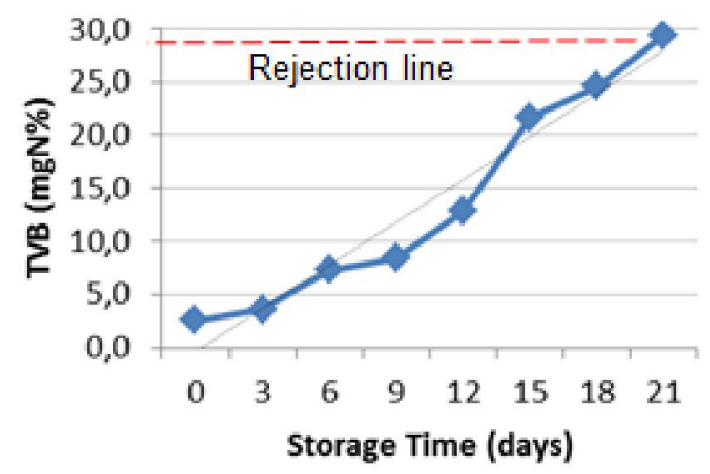

TMA

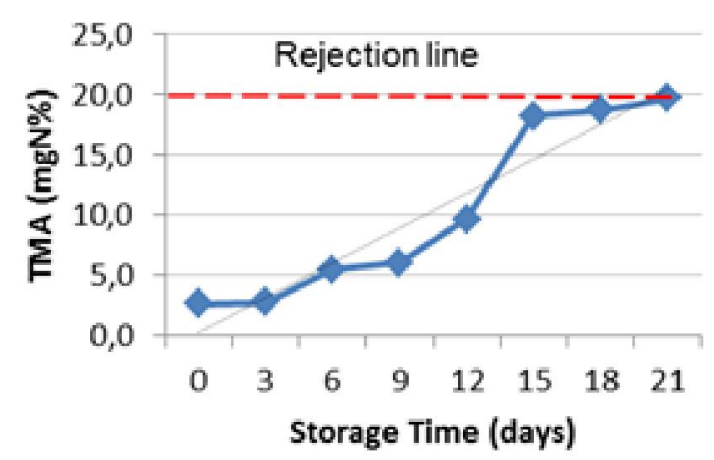

Figure 4. The changes of TVB and TMA values of fresh grouper fish during icing. 
boxes covered with ice flake $(1: 2 \mathrm{w} / \mathrm{w})$. The lower formation of TMA in fillets could be explained by the absence of viscera and head in which micro organisms that able to convert TMAO into TMA are concentrated. Moreover, in vacuum pack, oxygen present in the bag was limited resulted in lowering bacterial activity to convert non protein compound into biogenic amine including TMA. Relatively high content of TMA during icing in this experiment could be due to higher present of TMAO as well as bacterial reduction of TMAO in estuary grouper although those parameters were not analysed in this experiment. This was also stated by Kodom et al. (2014), that TMA content in fresh grouper was relatively high reaching up 12-16 $\mathrm{mgN} \%$. Regarding to the ratio of TMA and TVB content in estuary grouper fish, where TMA content was lower than that of TVB content, it is noted that degradation of the fish beyond the reduction of TMAO producing TMA as well as volatile compounds such as ammonia as proposed by Kodom et al. (2014).

\subsubsection{K value}

$\mathrm{K}$ value is objective index of fish freshness, calculated from the results of Adenosine Tri Phosphate (ATP) degradation ( Hiyama et al., 1972; Anon., 2009). The K-value gives a relative freshness rating based primarily on the autolytic changes which take place during post mortem storage of the muscle. A short coming of the K-value as a freshness index is that it varies between species owing to differences in rates of ATP degradation. It also varies with post-mortem time and temperature, storage conditions, handling conditions and method of killing (Olafsdóttir et al., 1997).

$\mathrm{K}$ value in this experiment increased slowly in the early time of storage up to 9 days of storage and increased moderately to at the remaining of storage (Figure 5) reaching up $40.54 \%$. The sample was considered unacceptable by trained panelists although this value was still below the rejection level $(60 \%)$ proposed by Ehira and Uchiyama (1987).

During 3 days storage, $K$ value was in the level of $5-6 \%$ supporting the Aleman statement that fish immediately after being killed have $\mathrm{K}$ value of $5 \%$ (Aleman et al., 1982). Additional time of storage (612 days storage) increased $K$ value into the level of $11.5-16.5 \%$ and less than $20 \%$, while in the remaining of storage (15-21 days of storage) considerable increased of $\mathrm{K}$ value was observed reaching up to $40.54 \%$ after 21 days. This phenomenon could be explained that in the early of storage, the amount of ATP in the flesh is still abundant, while the amount of ATP breakdown products is still low on the other hand, at the end of storage, the amount of ATP was depleted while the amount of ATP breakdown products such as inosine and hypoxanthine were abundance. This could be understood since the $\mathrm{K}$ value is defined as the ratio of the sum of inosine and hypoxanthine (HxR $+\mathrm{Hx}$ ) to the sum of ATP and related catabolites consisting of ADP, AMP, IMP, HxR and Hx (ATP + $\mathrm{ADP}+\mathrm{IMP}+\mathrm{HxR}+\mathrm{Hx}$ ) expressed as a percentage (Ehira and Uchiyama (1987). In wild white grouper (E.aeneus) stored in ice, the maximum $\mathrm{K}$ value was $90 \%$ stored for 22 days, while at the limit of acceptability $\mathrm{K}$ value was proximately $81 \%$, stored for 16 days (Ozogul et al., 2008). K value of yellow grouper (Epinephelusawoara) stored under vacuum packaging at $0{ }^{\circ} \mathrm{C}$ increased fast with time and reached $54.91 \%$ at the end of 15 days storage, keeping the middle level of freshness (Wei et al., 2010). Siah \& Ariff (2007) demonstrated that the K-value of fillets of fresh brackishwater grouper packed in plastic bag rose at a fairly moderate rate reaching over $60 \%$ from an

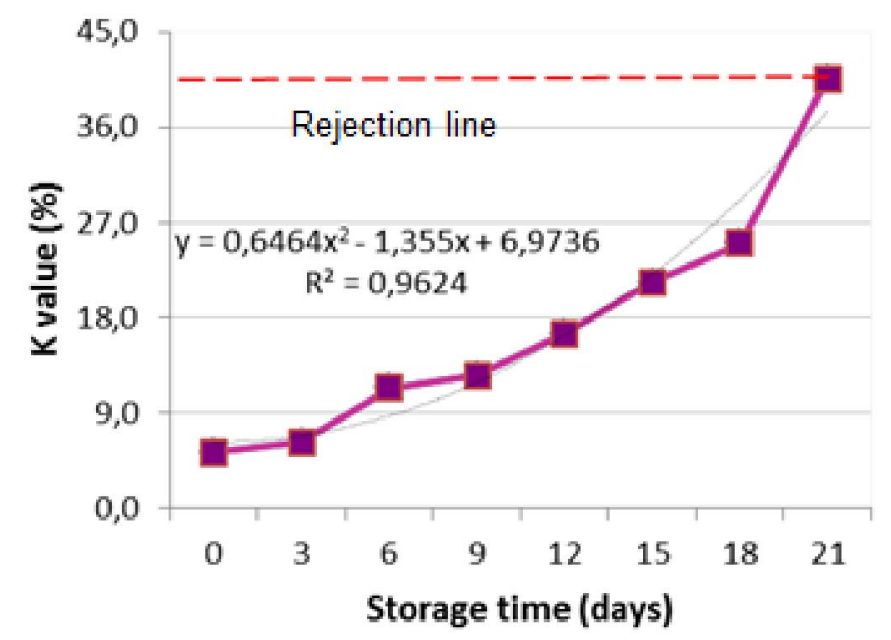

Figure 5.The changes of $\mathrm{K}$ value of fresh grouper fish during icing. 
initial value of $12 \%$ after 11 days of storage, while those packed in Modified Atmosphere Packaging reached $60 \%$ after 18 days of storage. There were some variations of $\mathrm{K}$ value among fish species and also between individuals of the same fish species, due to differences in rates of ATP (Hattula, 1997, Olafdottir et al., 1997). In addition, the method of killing also have an effect of the $\mathrm{K}$ value on the same species related to degraded products, i.e., inosine and hypoxanthine (Urbieta \& Ginés, 2000; Ahimbisibwe et al., 2010).

\subsubsection{Sensory characteristics in relation to chemical parameters}

Sensory evaluation was in good correlation with the results of the chemical assessment for estuary grouper stored in ice. The relationship between DPS and chemical parameters is shown in Figure 6-8.

When TVB and TMA values increased, DPS increased reflecting decrease in fish quality. DPS was correlated well with TVB as well as TMA with polynomial pattern where the increment rate of DPS was constant, while the rate of increment of either TVB or TMA was slower in the beginning of storage and more rapid for subsequent storage. This finding support previous study revealing both TVB-N and TMA level which did not increase much during the early stages of deterioration but followed by an exponential increase in the later period of storage (Sykes et al., 2009), therefore both TVB and TMA are not a reliable indicator of early changes in quality because they only rise as a result of bacterial activity during later stage of deterioration (Ozogul \& Ozogul, 2000).Similar polynomial pattern was also obtained in correlation between DPS and $\mathrm{K}$ value where the $\mathrm{K}$ value increased with slow rate during the first 9 days of storage and increased with relatively high rate during the following storage, while the increment rate of DPS occurred linearly during the whole of storage period. This indicates that $\mathrm{K}$ value is considerably affected by the early autolytic activity.

\section{DPS vs TVB}

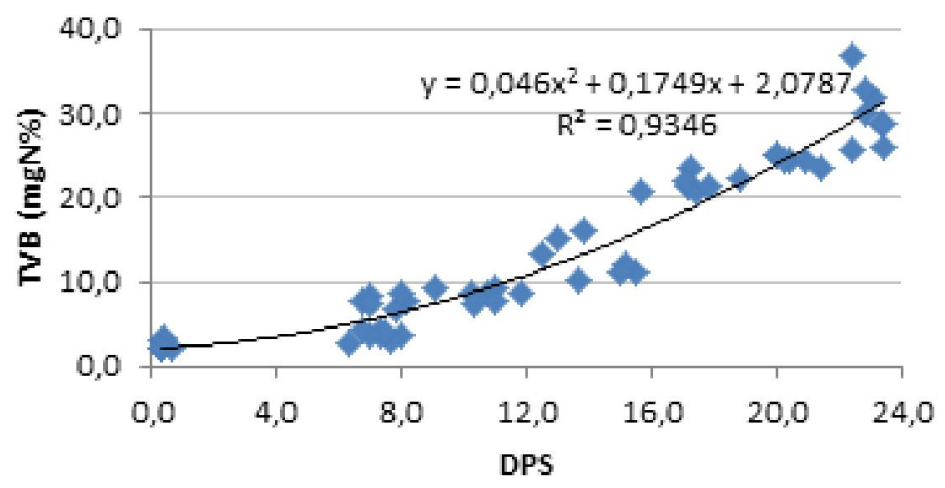

Figure 6. Correlation between DPS and TVB value of grouper fish during icing.

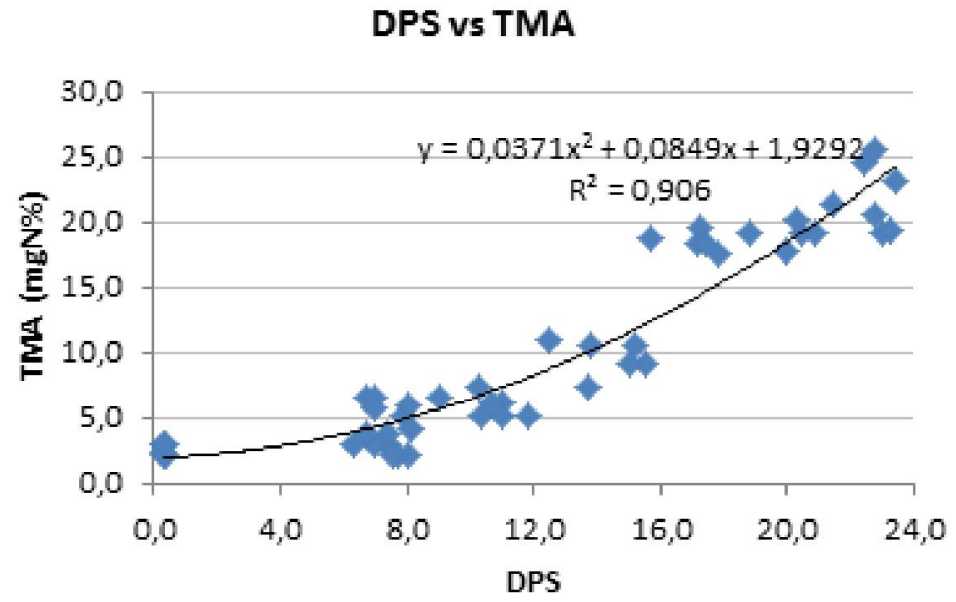

Figure 7. Correlation between DPS and TMA value of grouper fish during icing. 


\section{DPS vs $K$ value}

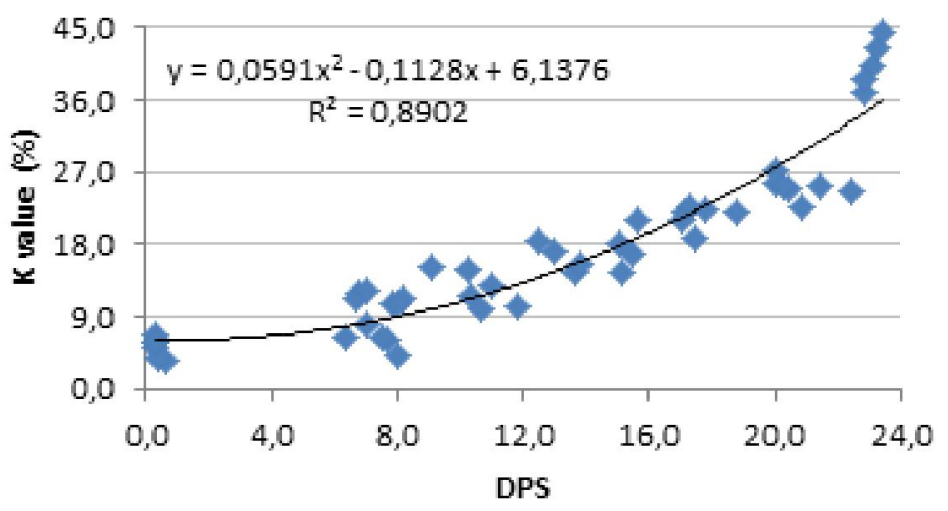

Figure 8. Correlation between DPS and K value of grouper fish during icing.

\section{Conclusions}

Based on the results of the experiments, it could be concluded that the results of sensory evaluation was in good agreement with the results of chemical assessment for estuary grouper stored in ice, where DPS correlated well with TVB, TMA as well as $\mathrm{K}$ value. In relation to the panelist's acceptance, estuary grouper fish stored in ice was rejected by panelists on 21 days of storage with TVB value of $29.43 \mathrm{mgN} \%$, TMA value of $19.70-22.10 \mathrm{mgN} \%$ and $\mathrm{K}$ value of $40.54 \%$.

\section{References}

Ahimbisibwe, J. B., Inoue, K., Shibata, T. , \& Aoki, T. (2010). Effect of bleeding on the quality of amberjack Seriola dumeriliand red sea bream Pagrus major muscle tissues during icedstorage. Fish Sci., 76, 389394

Alasalvar, C., Taylor, K.D.A., \&Shahidi, F. (2002). Comparative quality assessment of cultured and wild sea bream (Sparusaurata) stored in ice. J. Agric. Fd. Chem., 50, 2039 -2045

Aleman, M. P., Kakuda, K., \& Uchiyama, H. (1982). Partial Freezing as a Means of Keeping Freshness of Fish. Bull. Tokai. Reg. Fish. Res. Lab, 106, 11-26.

Anonymous. (2009). Freshness, Quality and Safety in Seafoods. http://seafood.ucedavis.edu. Assessed at 6 March, $2010: 32 \mathrm{pp}$

Ariyani, F., Murtini, J.T., \& Andayani, F. (2011). Penelitian Hubungan Parameter Sensori (Demerit Point Score), Kimia dan Mikrobiologi pada Kemunduran Mutu Ikan Nila Selama Pengesan. Jurnal Pasca Panen dan Bioteknologi Kelautan dan Perikanan, 6(1), 69 - 80.

Ariyani, F. \& Triwibowo, R. (2013). Penurunan Kesegaran Udang Vannamei selama Pengesan. Prosiding Seminar Nasional Inovasi Teknologi Pengolahan
Produkdan Bioteknologi Kelautan dan Perikanan V Tahun 2013, 125-128. ISBN : 978-602-19699-4-6.

Branch, A.C. \& Vail, A.M.A. (1985) Bringing fish inspection into the computer age. Food Technol. Aust. 37(8), 352-355

Bremner, H. A,. Olley, J., \& Vail, A. M. A. 1987. Estimating time-temperature effects by rapid systematic sensory methods. In: D.E.Kramer, J. Liston (Eds). Seafood Quality Determination. Amsterdam, New York: Elsevier. p. 413-434

David, G. \& Tom, P. D. (2006). Measuring, Maintaining Freshness In Aquaqulture Products. Global Aquaculture Advocate. Sep/Oct. 40-42

Ehira, S. \& Uchiyama, H. (1987).Determination of fish freshness using the $\mathrm{k}$ value and comments on some other biochemical changes in relation to freshness.In D. E. Kramer, \& J. Liston (Eds.), Seafood Quality Determination. Amsterdam: Elsevier Science Publishers. : 185 - 207

Esteban, M.A. (2012). An Overview of the Immunological Defenses in Fish Skin (Review Article).SRN Immunology.Bensussan, A., Flaño, E., Hayball, J.D. and Puccetti, P. (Eds.). Department of Cell Biology and Histology, Faculty of Biology, University of Murcia, Spain. Article ID 853470, 29 pp.

Etienne, M., Ifremer \& Nantes. (2005). Methods for chemical quality assessment-volatile amines as criteria for chemical quality assessment. SEAFOODplus - Traceability - Valid. Monique Etienne, Ifremer, Nantes, France, 22pp.

Ghaly, A.E., Dave, D., Budge, S., \& Brooks, M.S. (2010). Fish Spoilage Mechanisms and Preservation Techniques: Review. American Journal of Applied Sciences, 7(7), 859-877.

Hattula, T. (1997). Adenosine Tri Phosphate Breakdown Products as a Freshness Indicator in Some Fish Species and Fish Products.Finland, Technical Reserch Center. 48pp.

Howgate, P. (2010). A critical review of total volatile bases and trimethylamine as indices of freshness of fish. 
Part 2. Formation of the bases, and application in quality assurance. Electronic Journal of Environmental Agricultural and Food Chemistry, 9 (1), 58-88.

Hur, S. W., Lee, C. H., Lee, S. H., Kim, B. H., Kim, H. B., Baek, H. J., \& Lee, Y. D. (2013). Characterization of cholecystokinin-producing cells and mucussecreting goblet cells in the blacktip grouper, Epinephelus fasciatus. Tissue Cell., 45(2),153-157.

Huss, H.H. (1995). Quality and Quality Changes in Fresh Fish.FAO Fisheries Technical Paper. 348. Rome., FAO of the United Nations. $195 \mathrm{pp}$.

Jeyasekaran, G., Maheswari, K., Ganesan, P., Jeya Shakila, R., \& Sukumar, D. (2005). Quality changes in ice-stored tropical wire-netting reef cod (Epinephelusmerra). Journal of Food Processing and Preservation, 29, 165-182

Kodom, T., Amouzou,E., Nambo,P., Djaneye-Boundjou,G., \& Bawa, L.M. (2014). Chemical characterization of some fish sold in Lome (Togo). Journal of Chemical, Biological and Physical Sciences, 4(2), 1215-1223.

Masso-Silva, J.A., \& Diamond, G. (2014). Antimicrobial Peptides from Fish. Pharmaceuticals, 7, 265-310

Massaquoi, H., Sveinsdóttir, K., \& Martinsdóttir, E. (2011). Quality Changes of Fish from Catch to Processing and During Storage with Focus on Cooling Practices and Practical Application of Sierra Leone. Fisheries Training Programme. United Nation University. Iceland. 45pp

Martinsdottir, E., Sveinsdottir, K., Luten, J., Schelvis-Smit, R. \& Hyldig, G. (2001) Sensory Evaluation of Fish Freshness. Reference manual for the Fish Sector, IJmuiden, The Netherlands, QIM-Eurofish

Martinsdottir, E. (2002) Safety and Quality Issues in Fish Processing. Quality Management of Stored Fish. Boca Raton, CRC Press LLC. 19 pp.

Malle P., Eb P., \& Tailliez R. (1986). Determination of the quality of fish by measuring trimethylamine oxide reduction. International Journal of Food Microbiology, 3(3), 225-235.

Miwa, K. \& L.S., Ji. (1992). Laboratory Manual on Analytical Methods and Procedures for Fish and Fish Products. 2nd. Singapore: Marine Fish. Res, Dep., SEAFDEC

Okoro, C. C., Olusimbo, O., Aboaba, O. O., \& Babajide, O.J. (2010). Quality Assessment of a common Nigerian Marine Fish, Croaker (Pseudotolithu selongatus) under different Storage Conditions. New York Science Journal, 3(8), 25 - 36.
Olafdottir, G, Luten, J., Dalgaard, P., Careche, M., VerrezBagnis, V., Martinsdottir, E. \& Heia, K. (1997). Methods to Determine the Freshness of Fish in Research and Industry. Trends in Food Science and Technology. 8: 258-265.

Özogul, F. \& Özogul, Y. (2000). Comparision of Methods Used for Determination of Total Volatile Basic Nitrogen (TVB-N) in Rainbow Trout (Oncorhynchus mykiss). Turk. J. Zool., 24, 113-120

Ozogul, F., Ozogul, Y., \& Kuley, E. (2008). Nucleotide degradation and biogenic amine formation of wild white grouper (Epinephelusaeneus) stored in ice and at chill temperature $\left(4^{\circ} \mathrm{C}\right)$. Food Chemistry, 108, 933941.

Siah, W.M. \& Mohd, W. Ariff, (2007). Effect of modified atmosphere packaging and potassium sorbate on chemical, microbiological and sensorial properties of grouper (Epinephelus sp.) fillets. J. Trop. Agric. and Fd. Sc., 35(2), 237-243.

Sugama, K. (2013). Public Policy for Sustainable Development of Grouper Aquaculture in Indonesia. Retrieved from http://www.crawfordfund.org/assets/

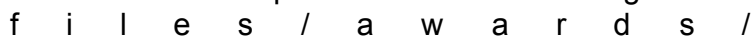
public_policies_aquaculture_Indonesia.pdf. Accessed on 5 November 2013

Sulieman, H.M.A, Lubna Osman Abdel Bari, L.O.A. \& Mohamed Abdel Hafiz, M.A. (2012). Determination of quality and shelf life of three marine fishes (coral trout, greasy grouper and red mouthed bream) based on Total Volatile Nitrogen test (TVN). J. Life Sci. Biomed. 2(5), 187-191

Sykes, A. V. Oliveira, A. R.,Domingues, P. M., Cardoso, C.M., Andrade, J. P., \& Nunes, M. L. (2009). Assessment of European cuttlefish (Sepia officinalis, L.) nutritional value and freshness under ice storage using a developed Quality Index Method (QIM) and biochemical methods. Food Science and Technology, 42, 424-432

Uchiyama, H., Ehira, S. \& Kato, N. (1972). Analytical methods for estimating freshness of fish. In: Utilization of Marine Products. Japan; OTCA; 206-214

Urbieta, F.J., \& Ginés R. (2000). Optimisation of slaughtering method in gilthead sea bream (Sparusaurata). Industrial application in fish farms. Global Quality Assessment in Mediterranean. Aquaculture. Zaragoza: CIHEAM. p. 71-77

Wei, X., Jian-rong, Li, Xue-peng, Li., \& Jun-li, Z. (2010). Quality changes of yellow grouper (Epinephelus awoara) fillets stored under vacuum packaging at 0 !. (abstract). Journal of Fisheries of China, 34(8), 12851294. 
Appendix 1. Score Sheets of DPS for a whole grouper

\begin{tabular}{|c|c|c|c|}
\hline Parameter Quality & Caracteristics & Scores & Description \\
\hline \multirow{16}{*}{ General appearance } & \multirow{4}{*}{ Appearance } & 0 & Very bright \\
\hline & & 1 & Bright \\
\hline & & 2 & Slightly dull \\
\hline & & 3 & Dull \\
\hline & \multirow{2}{*}{ Skin } & 0 & Firm \\
\hline & & 1 & Soft \\
\hline & \multirow{3}{*}{ Scales } & 0 & Firm \\
\hline & & 1 & Slightly loose \\
\hline & & 2 & Loose \\
\hline & \multirow{4}{*}{ Surface mucus } & 0 & Trasparent not slimy \\
\hline & & 1 & Slightly slimy \\
\hline & & 2 & Slimy \\
\hline & & 3 & Very slimy \\
\hline & \multirow{3}{*}{ Firmness } & 0 & Pre- rigor \\
\hline & & 1 & Rigor \\
\hline & & 2 & Post-rigor \\
\hline \multirow{11}{*}{ Eyes } & \multirow{3}{*}{ Clarity } & 0 & Clear \\
\hline & & 1 & Slightlycloudy \\
\hline & & 2 & Cloudy \\
\hline & \multirow{3}{*}{ Shape } & 0 & Normall \\
\hline & & 1 & Slightly sunken \\
\hline & & 2 & Sunken \\
\hline & \multirow{2}{*}{ Irish } & 0 & Visible \\
\hline & & 1 & Not visible \\
\hline & \multirow{3}{*}{ Blood } & 0 & No blood \\
\hline & & 1 & Slightly bloody \\
\hline & & 2 & Verybloody \\
\hline \multirow{10}{*}{ Gills } & \multirow{3}{*}{ Colour } & 0 & Characteristics red \\
\hline & & 1 & Slightly dark, Slightly faded \\
\hline & & 2 & Very dark, very faded \\
\hline & \multirow{3}{*}{ Mucus } & 0 & Transparent not slimy \\
\hline & & 1 & Moderate \\
\hline & & 2 & Exes sive \\
\hline & \multirow{4}{*}{ Smell } & 0 & Fresh oily, metallic, seaweed \\
\hline & & 1 & Fishy \\
\hline & & 2 & Stale \\
\hline & & 3 & Spoilt \\
\hline \multirow{7}{*}{ Belly } & \multirow{4}{*}{ Discoloration } & 0 & Absent \\
\hline & & 1 & Detectable \\
\hline & & 2 & Moderate \\
\hline & & 3 & Exessive \\
\hline & \multirow{3}{*}{ Firmness } & 0 & Firm \\
\hline & & 1 & Soft \\
\hline & & 2 & Burst \\
\hline & & 0 & Normal \\
\hline & Condition & 1 & Slightly break, exudes \\
\hline & & 2 & Excessive, opening \\
\hline Vent & & 0 & Fresh \\
\hline & & 1 & Neutral \\
\hline & Smell & 2 & Fishy \\
\hline & & 3 & Spoilt \\
\hline & & 0 & Opales cent \\
\hline & Stains & 1 & Greyish \\
\hline Belly cavity & & 2 & Yellow-brown \\
\hline Belly cavily & & 0 & Red \\
\hline & Blood & 1 & Dark red \\
\hline & & 2 & Brown \\
\hline
\end{tabular}

